\title{
Survey of the Aflatoxin Gene Cluster in Aspergilli from Hungarian Crops
}

\author{
SZILVIA KOVÁCS and TÜNDE PUSZTAHELYI* \\ Central Laboratory of Agricultural and Food Products, Faculty of Agricultural and Food Sciences and \\ Environmental Management, University of Debrecen, H-4032 Debrecen, Böszörményi út 138, Hungary
}

(Received: 25 May 2017; accepted: 8 June 2017)

\begin{abstract}
Climate changes in Europe, which is characterized by the decrease of rainy days and the higher average temperature at summer, significantly increase the spreading of Aspergillus species and aflatoxin B1 contamination of the staple food and feed materials. The aim of our study was to estimate the possibility of the aflatoxin production of the Aspergilli on crops. From the isolates that were gained from crop samples, higher than $40 \%$ of the Aspergillus isolates contained norA, aflR and omtA genes from the aflatoxin genes cluster. Most of these isolates (63\%) showed high homology with A. flavus, while three isolates showed high homology to A. tritici/A. candidus, one to A. cristatus/A. amstelodami and one strain showed the highest homology to A. tritici. Six from the A. flavus isolates (85.7\%) with norA, aflR and omtA genes could produce aflatoxin $\mathrm{B} 1$ on malate extract agar medium. Parallel PCR and toxin measurements are recommended to evaluate the potentiality of aflatoxin production.
\end{abstract}

Keywords: aflatoxin B1, Aspergillus flavus, PCR, ITS.

Abbreviations: AFB1, aflatoxin B1

Mycotoxin production by microscopic filamentous fungi has always caused a crucial problem worldwide especially in monocultures and in storage crops. Besides some Rhizopus strains (Erdogan, 2004; Cary et al., 2005; Varga et al., 2009), Aspergillus flavus, A. parasiticus (Mayer et al., 2003; Schmidt-Heydt et al., 2008) are the well-known producers of the carcinogenic secondary metabolite aflatoxins (AFs). A. flavus of the yellow aspergilli lacks host specificity (St Leger et al., 2000) as it can attack successfully the seeds of both monocots and dicots (cotton, maize, groundnuts and also other nuts) and derive acetyl-CoA from fatty acids from kernels for the biosynthesis of AFs (Howlett, 2006). One of the aflatoxin forms, aflatoxin B1 (AFB1), is the most toxic compound known that commonly checked worldwide especially in oily seeds, nuts and fruits. Preharvest contamination of the crops with AFs is usual resulting in significant economic losses to farmers, but the fungi also cause AFB1 spoilage post-harvest. The optimum temperature of the AF production is about $32-38{ }^{\circ} \mathrm{C}$ for A. flavus. Therefore, aflatoxicosis occurs primarily in tropical and mediterranean areas. However, climate change, what characterized by the decrease in summer precipitation and increase the average temperature (Padányi and Halász, 2012) worldwide (the global temperature is expected to increase by between

\footnotetext{
* Corresponding author; e-mail: pusztahelyi@agr.unideb.hu
} 
$+2{ }^{\circ} \mathrm{C}$ and $+5^{\circ} \mathrm{C}$ ), significantly enhances the danger of AF contamination of the staple food/feed materials, even where it was not common before (Medina et al., 2014).

The gene cluster of the AF biosynthesis is about $75 \mathrm{kbp}$ in A. flavus and A. parasiticus (Yu et al., 2004a; Yu et al., 2004b) and norA, omtA, aftR genes, which are essential for the aflatoxin production, are the parts of the cluster. The aim of this work was to estimate the incidence of aflatoxigenic Aspergillus spp. on crops by the determination of the presence of the norA, omtA, and aflR genes and the potential of AF B1 production in the fungal isolates.

\section{Materials and Methods}

Isolation and cultivation of Aspergillus spp. and Aspergillus flavus NRRL 11611 reference strain

Chloramphenicol-yeast extract-glucose (CYG) agar was inoculated with the decimal dilutions of different grounded grains (corn and wheat) and cultivated for 5 days at $30{ }^{\circ} \mathrm{C}$. The fungal colonies, which were identified microscopically as Aspergillus, were collected and streaked onto malate agar (MA) medium $\left[20 \mathrm{~g} \mathrm{l}^{-1}\right.$ glucose, $10 \mathrm{~g} \mathrm{l}^{-1}$ malate extract, $5 \mathrm{~g} \mathrm{l}^{-1}$ yeast extract, $15 \mathrm{~g} \mathrm{l}^{-1}$ agar].

\section{Detection of the genes in AF cluster by multiplex PCR}

The mycelia of the fungal isolates and A.flavus NRRL 11611 were collected from the surface of the MA plates after 5 days at $30{ }^{\circ} \mathrm{C}$ incubation. The mycelia were disrupted with MagNA Lyser Green (Roche) beads. The DNA was isolated by the Nucleospin Plant II kit (Macherey-Nagel) according to the description of the manufacturer. For the PCR reactions, Phusion High-Fidelity PCR Kit (Thermo Scientific) was applied with the following primer pairs (Varga et al., 2011):

nor 1: 5-ACC GCT ACG CCG GCA CTC TCG GCA -3

nor2: 5-GTT GGC CGC CAG CTT CGA CAC AGC -3

aflR-R: 5-TGG KGC CGA CTC GAG GAA YGG GT -3

aflR-F: 5-GGG ATA GCT GTA CGA GTT GTG CCA -3

omt 1 : 5-GTG GAC GGA CCT AGT CCG ACA TCA C -3

omt 2: 5-GTC GGC GCC ACG CAC TGG GTT GGG G -3

In the PCR, $12.4 \mu 1 \mathrm{H}_{2} \mathrm{O}$, four $\mu 1$ 5X Phusion HF buffers, $0.4 \mu 110 \mathrm{mM}$ dNTPs, one $\mu 1$ forward primer, one $\mu 1$ reverse primer, one $\mu 1$ template DNA, and $0.2 \mu 1$ Phusion Enzyme were loaded in the $20 \mu \mathrm{l}$ reaction volume. The reaction was done in Eppendorf Mastercycler, and the settings were: $98{ }^{\circ} \mathrm{C} 30 \mathrm{sec}, 98^{\circ} \mathrm{C} 10 \mathrm{sec}, 65^{\circ} \mathrm{C} 30 \mathrm{sec}, 72{ }^{\circ} \mathrm{C} 30$ sec, repeated 30 times. That was followed by a $72{ }^{\circ} \mathrm{C} 10 \mathrm{~min}$ and cooling at $4{ }^{\circ} \mathrm{C}$. The reaction was optimized and verified on DNA template isolated from $A$. flavus NRRL 11611 strain. 


\section{Determination of the species of the aflatoxigenic Aspergillus isolates}

The strains that were proven to contain the norA, omtA or aflR genes were also applied in PCR with ITS1 and ITS4 primer pairs (White et al., 1990).

ITS1: 5-TCC GTA GGT GAA CCT GCG G -3

ITS4: 5-TCC TCC GCT TAT TGA TAT GC -3

The PCR products were purified from the $1 \%$ agarose gel after gel electrophoresis and sequenced (Biomi Ltd., Gödöllö, Hungary). The DNA sequences were analyzed using MEGA 7 software version 7.0.14. and blasted in the NCBI database (http://blast.ncbi.nlm. nih.gov/Blast.cgi; version 2016. 03. 01.).

\section{Detection of aflatoxin B1}

The MA medium together with the surface culture was collected in sterile Stomacher homogenizer bag and, with $10 \mathrm{ml}$ chloroform, it was homogenized in Stomacher homogenisator (Masticator, IUL Instruments) for $2 \mathrm{~min}$, and the process was repeated once more. The homogenized culture was filtered through filter paper (Macherey-Nagel MN 619) into spherical flasks and was evaporated in Rotavapor R114 (Büchi). After the addition of $2 \mathrm{ml}$ mobile phase (methanol:water, 45:55) the solute was filtered through Millex-GV $0.22 \mu \mathrm{m}$ filter (Merck-Millipore).

The AFB1 content of $20 \mu \mathrm{l}$ samples was determined by HPLC technique on Hibar 125-4 Lichrospher 100RP-18 (5 $\mu \mathrm{m})$ column with $1 \mathrm{ml} \mathrm{min}^{-1}$ flow rate of the mobile phase and detected by a fluorescence detector at ex360 nm, em440 nm. Biopure aflatoxin B1 standard solution (Romer Labs) was applied to the column.

\section{Results}

\section{Potentially aflatoxigenic isolates are of high incidence}

From corn kernels and wheat grains, 72 isolates of Aspergillus spp. were collected in 2014-2015. After 5 days of cultivation, the mycelial DNA was extracted and applied in multiplex PCR where the norA, omtA or aflR genes of the AF gene cluster were targeted (Fig. 1). After the gel electrophoresis of the amplified sequences, it was concluded that 33 isolates $(46 \%)$ were potentially able to produce aflatoxins, as they contained at least one of the targeted gene, while 17 isolates (23.6\%) gave signals for all the targeted genes (Table 1).

The isolates, which contained at least one of the targeted genes of the AF gene cluster, were considered as potentially aflatoxigenic strain. The ITS region of these isolates was also amplified and sequenced. BLAST searches revealed that most of these isolates $(63 \%)$ showed high (more than 97\%) homology with A. flavus, while three isolates showed high homologies to A. tritici/A. candidus, one to A. cristatus/A. amstelodami and one strain showed the highest homology to A. tritici (Table 1), but any A. parasiticus were 
1. 2.

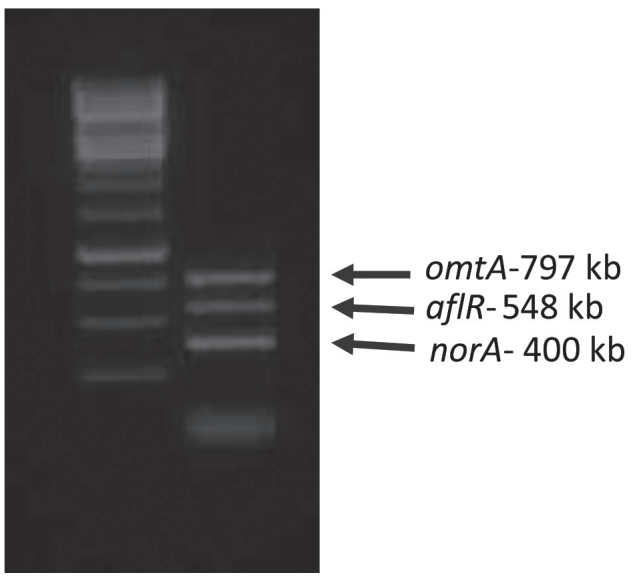

Fig. 1. Picture of the agarose gel electrophoresis of the multiplex PCR performed with primers designed for the $o m t A, a f l R$ and norA genes. Lane 1: $1 \mathrm{~kb}$ DNA ladder; Lane 2.: DNA bands after multiplex PCR on the genomic DNA isolated from A. flavus NRRL 11611

detected. Interestingly, for eight isolates, attempts to amplify the ITS region within the ITS1-ITS4 primer pairs were not successful applying the standard PCR protocol as any products were detected after agarose gel electrophoresis.

The AFB1 production of the nor A, aflR and/or omtA positive isolates was tested on MA medium, and seven isolates produced a detectable concentration of the toxic compound (Table 2). These all were identified as A. flavus and six out of the seven isolates contained all tested genes and produced AFB1. Interestingly, one A. flavus strain, from that only norA positivity was proven, also produced detectable AFB1 (Table 2).

\section{Discussion}

The first question was how many genes should be targeted in a PCR to detect aflatoxigenic fungal species. Geisen (1996) concluded that multiplex PCR with three sets of primers specific for three structural genes (norA, aflR, and $o m t A$ ) of the aflatoxin pathway could differentiate the aflatoxin producing fungi, A. flavus and A. parasiticus from others, but not aflatoxin producing and non-producing strains of the same species. However, other Aspergillus species also contained these gene sequences. Moreover, even a higher number of primer pairs did not ensure the identification of aflatoxin-producing strains (e.g. Criseo et al., 2001; Rashid et al., 2008). The statistics revealed that norA positivity had the highest relevance for aflatoxigenic organisms (e.g. Rashid et al., 2008), and detection of $a f l R$ was also marked a potentially aflatoxigenic isolate. Based on our studies also norA and aflR genes were the most frequently detected genes (Table 2).

Aspergillus flavus was the most frequently isolated organism, but some other Aspergillus species were also detected. One of them, Aspergillus tritici has been suggested 
Table 1

The characterization of the fungal isolates with aflatoxin gene cluster genes

\begin{tabular}{|c|c|c|c|c|c|}
\hline No. & norA & $a f l R$ & omtA & $\begin{array}{l}\text { Homology } \\
\text { (BLASTs of the ITS sequences) }\end{array}$ & $\begin{array}{l}\mathrm{AF} \mathrm{B} 1 \\
\text { production on MA }\end{array}$ \\
\hline 1. & + & + & + & $\begin{array}{l}\text { Aspergillus flavus } \\
\text { ITS 1-99\%, ITS 4-99\% }\end{array}$ & n.d. ${ }^{1}$ \\
\hline 6. & + & - & - & $\begin{array}{l}\text { Aspergillus flavus } \\
\text { ITS 1-98\%, ITS 4-99\% }\end{array}$ & $10.8 \mathrm{ng} / \mathrm{ml}$ \\
\hline 7. & + & + & + & $\begin{array}{l}\text { Aspergillus flavus } \\
\text { ITS } 1-98 \% \text {, ITS } 4-84 \%\end{array}$ & n.d. \\
\hline 9. & + & + & + & $\begin{array}{l}\text { Aspergillus flavus } \\
\text { ITS } 1-100 \% \text {, ITS } 4-100 \%\end{array}$ & $643 \mathrm{ng} / \mathrm{ml}$ \\
\hline 11. & + & + & + & n.d. & n.d. \\
\hline 12. & + & + & + & $\begin{array}{l}\text { Aspergillus flavus } \\
\text { ITS 1-99\%, ITS 4-99\% }\end{array}$ & $12.7 \mathrm{ng} / \mathrm{ml}$ \\
\hline 14. & + & + & - & $\begin{array}{l}\text { Aspergillus tritici/A. candidus } \\
\text { ITS4-99\% }\end{array}$ & n.d. \\
\hline 15. & + & + & + & $\begin{array}{l}\text { Aspergillus cristatus/A. amstelodami } \\
\text { ITS } 1-100 \% \text {, ITS } 4-100 \%\end{array}$ & n.d. \\
\hline 18. & - & + & - & n.d. & n.d. \\
\hline 21. & + & + & - & $\begin{array}{l}\text { Aspergillus tritici } \\
\text { ITS } 1-100 \% \text {, ITS } 4-100 \%\end{array}$ & n.d. \\
\hline 23. & - & + & - & n.d. & n.d. \\
\hline 27. & - & + & - & $\begin{array}{l}\text { Aspergillus flavus } \\
\text { ITS 1-99\%, ITS 4-99\% }\end{array}$ & n.d. \\
\hline 28. & + & + & + & $\begin{array}{l}\text { Aspergillus flavus } \\
\text { ITS 1-99\%, ITS 4-99\% }\end{array}$ & n.d. \\
\hline 29. & + & + & + & $\begin{array}{l}\text { Aspergillus flavus } \\
\text { ITS } 1-99 \%, \text { ITS } 4-100 \%\end{array}$ & $9 \mathrm{ng} / \mathrm{ml}$ \\
\hline 30. & + & + & + & $\begin{array}{l}\text { Aspergillus flavus } \\
\text { ITS 1-97\%, ITS 4-99\% }\end{array}$ & n.d. \\
\hline 33. & + & + & + & $\begin{array}{l}\text { Aspergillus flavus } \\
\text { ITS 1-98\%, ITS 4-99\% }\end{array}$ & n.d. \\
\hline 34. & - & + & - & $\begin{array}{l}\text { Aspergillus flavus } \\
\text { ITS } 1-97 \% \text {, ITS } 4-100 \%\end{array}$ & n.d. \\
\hline 36. & - & + & - & n.d. & n.d. \\
\hline 37. & + & + & + & $\begin{array}{l}\text { Aspergillus flavus } \\
\text { ITS } 1-98 \%, \text { ITS } 4-100 \%\end{array}$ & n.d. \\
\hline 38. & + & + & + & $\begin{array}{l}\text { Aspergillus flavus } \\
\text { ITS } 1-99 \% \text {, ITS } 4-100 \%\end{array}$ & $81 \mathrm{ng} / \mathrm{ml}$ \\
\hline 44. & + & + & - & $\begin{array}{l}\text { Aspergillus flavus } \\
\text { ITS 1-99\%, ITS 4-99\% }\end{array}$ & n.d. \\
\hline 47. & - & + & + & n.d. & n.d. \\
\hline 51. & + & + & + & $\begin{array}{l}\text { Aspergillus flavus } \\
\text { ITS } 1-99 \% \text {, ITS 4-99\% }\end{array}$ & n.d. \\
\hline 53. & + & + & + & $\begin{array}{l}\text { Aspergillus flavus } \\
\text { ITS 1-99\%, ITS 4-99\% }\end{array}$ & $2.5 \mathrm{ng} / \mathrm{ml}$ \\
\hline
\end{tabular}


Table 1 continued

\begin{tabular}{|c|c|c|c|c|c|}
\hline No. & norA & $a f l R$ & omtA & $\begin{array}{l}\text { Homology } \\
\text { (BLASTs of the ITS sequences) }\end{array}$ & $\begin{array}{l}\mathrm{AF} \mathrm{B} 1 \\
\text { production on MA }\end{array}$ \\
\hline 56. & - & + & - & $\begin{array}{l}\text { Aspergillus tritici/A. candidus } \\
\text { ITS } 1-100 \% \text {, ITS 4-99\% }\end{array}$ & n.d. \\
\hline 59. & + & + & + & $\begin{array}{l}\text { Aspergillus tritici/A. candidus } \\
\text { ITS } 1-100 \% \text {, ITS } 4-99 \%\end{array}$ & n.d. \\
\hline 60. & + & + & + & n.d. & n.d. \\
\hline 61. & - & + & - & $\begin{array}{l}\text { Aspergillus flavus } \\
\text { ITS 1-99\%, ITS 4-99\% }\end{array}$ & n.d. \\
\hline 62. & + & + & + & $\begin{array}{l}\text { Aspergillus flavus } \\
\text { ITS } 1-99 \% \text {, ITS } 4-100 \%\end{array}$ & $4.2 \mathrm{ng} / \mathrm{ml}$ \\
\hline 65. & - & + & - & n.d. & n.d. \\
\hline 70. & + & + & - & $\begin{array}{l}\text { Aspergillus flavus } \\
\text { ITS 1-99\%, ITS 4-99\% }\end{array}$ & n.d. \\
\hline 71. & - & + & - & $\begin{array}{l}\text { Aspergillus flavus } \\
\text { ITS } 1-100 \% \text {, ITS 4-99\% }\end{array}$ & n.d. \\
\hline 72. & - & + & - & $\begin{array}{l}\text { Aspergillus flavus } \\
\text { ITS 1-99\%, ITS 4-87\% }\end{array}$ & n.d. \\
\hline
\end{tabular}

${ }^{1}$ not detected.

Table 2

Summary of the detection of the omtA, norA and aflR genes and the production of AFB1 of the Aspergillus isolates

\begin{tabular}{|c|c|c|c|c|c|}
\hline Organism & $\begin{array}{c}\text { norA } \\
\text { aflR } \\
\text { omtA }\end{array}$ & aflR & $\begin{array}{c}\text { norA } \\
\text { aflR }\end{array}$ & $\begin{array}{l}a f l R \\
\text { omtA }\end{array}$ & norA \\
\hline A. flavus $(\mathrm{n}=21)$ & $\begin{array}{c}13 \\
(2.5-643 \mathrm{ng} / \mathrm{ml})^{1}\end{array}$ & 5 & 2 & - & $\begin{array}{c}1 \\
(10.8 \mathrm{ng} / \mathrm{ml})^{1}\end{array}$ \\
\hline $\begin{array}{l}\text { A. triticil } \\
\text { A. candidus }(\mathrm{n}=4)\end{array}$ & 1 & 1 & 2 & - & - \\
\hline $\begin{array}{l}\text { A. cristatus/ } \\
\text { A. amstelodami }(\mathrm{n}=1)\end{array}$ & 1 & - & - & - & - \\
\hline Not determined $(n=7)$ & 2 & 4 & - & 1 & - \\
\hline Total $(n=33)$ & $17(51.5 \%)$ & $10(30.3 \%)$ & $4(12.1 \%)$ & 1 & 1 \\
\hline
\end{tabular}

${ }^{1} \mathrm{AFB} 1$ production on MA

to be the synonym of $A$. candidus previously, however, sequence data indicated that this is a valid species (Varga et al., 2009), and a common contaminant of grains. As it was communicated before, it caused respiratory disease in humans (Krysinska-Traczyk and Dutkiewicz, 2000); however, A. tritici cannot grow on $37^{\circ} \mathrm{C}$, therefore, the statement can be questionable.

A. cristatus or A. amstelodami was also found containing all the three tested gene sequences. A. amstelodami is capable producing intermediates of the aflatoxin biosynthetic pathway as sterigmatocystin production has been proven (Bukelskienè et al., 2006). A. cristatus was also investigated recently (Ge et al., 2016) and some genes of the afla- 
toxin gene cluster were found but not in a cluster structure. Under high and low osmolarity, the gene expressions were found to react on the environmental stress, but AF B1 production was not detected.

Our studies revealed the importance of the aflatoxin measurements of crops. Nucleic acid-based detection of the potentially aflatoxigenic strains could give only a presumption of the danger while the intensity of the mycotoxin production strongly depends on the environmental conditions ( $\mathrm{N}$ and $\mathrm{C}$ sources, temperature, water activity $\left(\mathrm{a}_{\mathrm{w}}\right)$, etc.; see e.g. Prandini et al., 2009). Medina et al. (2014) examined the effects of interacting conditions of $\mathrm{a}_{\mathrm{w}} \times$ temperature $\times$ elevated $\mathrm{CO}_{2}$ in vitro and on maize grain and found positive effect on gene expressions of the key genes of the aflatoxin gene cluster, while the growth of the fungal cultures was not affected.

Among the isolates that were gained from crop samples, higher than $40 \%$ of the fungi were capable of producing aflatoxins. That fact is critical knowing that the climate changes can increase the possibility of the contamination of the crops with Aspergilli and aflatoxins on fields. These facts increased the significance of the prevention on fields.

\section{Conflict of interests}

The authors declare no conflict of interest.

\section{Acknowledgements}

The authors are thankful for the anonymous reviewers for valuable comments and additions.

\section{Literature}

Bukelskienè, V., Baltriukienè, D. and Repečkienè, J. (2006): Study of health risks associated with Aspergillus amstelodami and its mycotoxic effects. Ekologija 3, 42-47.

Cary, J. W., Klich, M. A. and Beltz, S. B. (2005): Characterization of aflatoxin-producing fungi outside of Aspergillus section Flavi. Mycologia 97, 425-432.

Criseo, G., Bagnara, A. and Bisignano, G. (2001): Differentiation of aflatoxin-producing and non-producing strains of Aspergillus flavus group. Lett. Appl. Microbiol. 33, 291-295.

Erdogan, A. (2004): The aflatoxin contamination of some pepper types sold in Turkey. Chemosphere 56, $321-325$.

Ge, Y., Wang, Y., Liu, Y., Tan, Y., Ren, X., Zhang, X., Hyde, K. D., Liu, Y. and Liu, Z. (2016): Comparative genomic and transcriptomic analyses of the Fuzhuan brick tea-fermentation fungus Aspergillus cristatus. BMC Genomics. 7:428. doi: 10.1186/s12864-016-2637-y.

Geisen, R. (1996): Multiplex polymerase chain reaction for the detection of potential aflatoxin and sterigmatocystin producing fungi. System. Appl. Microbiol. 19, 388-392.

Howlett, B. J. (2006): Secondary metabolite toxins and nutrition of plant pathogenic fungi. Curr. Opin. Plant Biol. 9, 371-375. doi:10.1016/j.pbi.2006.05.004.

Krysinska-Traczyk, E. and Dutkiewicz, J. (2000): Aspergillus candidus: a respiratory hazard associated with grain dust. Ann. Agric. Environ. Med. 7, 101-109.

Mayer, Z., Färber, P. and Geisen, R. (2003): Monitoring the production of aflatoxin B1 in wheat by measuring the concentration of nor-1 mRNA. Appl. Environ. Microbiol. 69, 1154-1158.

Medina, A., Rodriguez, A. and Magan, N. (2014): Effect of climate change on Aspergillus flavus and aflatoxin B1 production. Front. Microbiol. 5, 348. doi: 10.3389/fmicb.2014.00348 
Padányi, J. and Halász, L. (2012): The effect of climate changing. http://uni-nke.hu/downloads/konyvtar/kovasz/ padanyi_klimavaltoz_tanulm.pdf

Prandini, G., Tansini, S., Sigolo, L., Filippi, M. and Laporta, G. (2009): On the occurrence of aflatoxin M1 in milk and dairy products. Food and Chemical Toxicology 47, 984-991.

Rashid, M., Khalil, S., Ayub, N., Ahmed, W. and Khan, G. (2008): Categorization of Aspergillus flavus and Aspergillus parasiticus isolates of stored wheat grains in to aflatoxinogenics and non-aflatoxinogenics. Pak. J. Bot. 40, 2177-2192.

Schmidt-Heydt, M., Magan, N. and Geisen, R. (2008): Stress induction of mycotoxin biosynthesis genes by abiotic factors. FEMS Microbiology Letters 284, 142-149.

St Leger, R. J., Screen, S. E. and Shams-Pirzadeh, B. (2000): Lack of host specialization in Aspergillus flavus. Appl. Environ. Microbiol. 66, 320-324.

Varga, J., Frisvad, J. C. and Samson, R. A. (2009): A reappraisal of fungi producing aflatoxins. World Mycotoxin J. 2, 263-277.

Varga, J., Frisvad, J. C. and Samson, R. A. (2011): Two new aflatoxin producing species, and an overview of Aspergillus section Flavi. Studies in Mycology 69, 57-80. doi:10.3114/sim.2011.69.05.

White, T. J., Bruns, T. D., Lee, S. B. and Taylor, J. W. (1990): Amplification and direct sequencing of fungal ribosomal RNA genes for phylogenetics. In: M. A. Innis, D. H. Gelfand, J. J. Sninsky and T. J. White (eds): PCR Protocols - a Guide to Methods and Applications. Academic Press, San Diego, CA, pp. 315-322.

Yu, J., Bhatnagar, D. and Cleveland, T. D. (2004a): Completed sequence of aflatoxin pathway gene cluster in Aspergillus parasiticus. FEBS Letters 564, 126-130.

Yu, J., Chang, P. K., Ehrlich, K. C., Cary, J. W., Bhatnagar, D., Cleveland, T. E., Payne, G. A., Linz, J. E., Woloshuk, C. P. and Bennett, J. W. (2004b): Clustered pathway genes in aflatoxin biosynthesis. Appl. and Environmental Microbiology 70, 1253-1262. 